\title{
Cyclin-dependent kinase 2 inhibitor SU9516 increases sensitivity of colorectal carcinoma cells Caco-2 but not HT29 to BH3 mimetic ABT-737
}

\author{
Andrea Štefaniková ${ }^{1}$, Katarína Klačanová 2 , Ivana Pilchová ${ }^{2}$, Jozef Hatok ${ }^{1}$ and Peter Račay ${ }^{1,2}$ \\ ${ }^{1}$ Department of Medical Biochemistry, Jessenius Faculty of Medicine in Martin, Comenius University in Bratislava, Martin, \\ Slovakia \\ ${ }^{2}$ Biomedical Center, Jessenius Faculty of Medicine in Martin, Comenius University in Bratislava, Martin, Slovakia
}

\begin{abstract}
Colorectal carcinoma (CRC) that represents one of the major causes for cancer related death in humans is often associated with over-expression of anti-apoptotic proteins of Bcl-2 family. The aim of presented study was to determine the effect of ABT-737 inhibitor of anti-apoptotic proteins Bcl-2, Bcl- $\mathrm{X}_{\mathrm{L}}$ and Bcl-w as well as cyclin-dependent kinase 2 (CDK2) inhibitor SU9516 alone and in combination with ABT-737 on survival of colorectal cell lines HT29 and Caco-2. We have shown that both Caco-2 and HT29 cells that are relatively resistant to ABT-737 are also partially sensitive to SU9516, which increased sensitivity of Caco-2 but not HT29 cells to ABT-737. Increased sensitivity of Caco-2 cells to ABT-737 after addition of SU9516 correlated well with SU9516-induced decrease of Mcl-1 expression while we have not observed downregulation of Mcl-1 after the treatment of HT29 cells with SU9516. Instead of this, we have shown that treatment of HT29 cells with SU9516 is associated with decreased expression of tumour suppressor protein p53. Our findings provide a rationale for clinical use of $\mathrm{Bcl}-2$ family inhibitors in combination with CDK2 inhibitors for treatment of Mcl-1-dependent colorectal tumours associated with expression of Bcl-2, Bcl- $\mathrm{X}_{\mathrm{L}}$ and $\mathrm{Bcl}-\mathrm{w}$ proteins. In addition, we have shown potential of CDK2 inhibitors for treatment of tumours expressing $\mathrm{R} 273 \mathrm{H}$ mutant $\mathrm{p} 53$.
\end{abstract}

Key words: Cell death - Apoptosis - Bcl-2 family proteins - Cyclin-dependent kinase Colorectal carcinoma

\section{Introduction}

Colorectal carcinoma (CRC) represents one of the major causes for cancer-related death in humans (Ferlay et al. 2010). Even efficiency of novel and targeted therapeutic approaches that are rapidly emerging is not high enough and the prognosis in the metastatic stage (UICC IV) is poor (Lansdorp-Vogelaar et al. 2009).

In addition to different molecular hallmarks of CRC (Dienstmann et al. 2017), it has been documented that anti-apoptotic proteins of Bcl-2 family Bcl-w (Wilson et al. 2000) and Bcl- $\mathrm{X}_{\mathrm{L}}$ (Krajewska et al. 1996; Zhang et al.

Correspondence to: Peter Račay, Biomedical Center Martin and Department of Medical Biochemistry, Jessenius Faculty of Medicine, Comenius University, Mala Hora 4D, 03601 Martin, Slovakia E-mail: racay@jfmed.uniba.sk 2008a; Scherr et al. 2016) are frequently over-expressed in colorectal carcinomas and patients with high $\mathrm{Bcl}-\mathrm{X}_{\mathrm{L}}$ expression showed significantly poorer overall survival than those with low Bcl- $\mathrm{X}_{\mathrm{L}}$ expression (Jin-Song et al. 2011). Proteins of Bcl-2 family essential regulators of mitochondrial apoptosis (Czabotar et al. 2014; Hatok and Racay 2016) are emerging interests in development of new anticancer agents and several small molecules with a potential of binding to anti-apoptotic proteins of Bcl-2 family were developed during past 10 years (Delbridge et al. 2016; Ashkenazi et al. 2017; Schenk et al. 2017). ABT-737 is a small BH3-only mimetic molecule that binds to the anti-apoptotic $\mathrm{Bcl}-2$ family proteins $\mathrm{Bcl}-2, \mathrm{Bcl}-\mathrm{X}_{\mathrm{L}}$, and Bcl-w (Oltersdorf et al. 2005). Binding of ABT-737 to Bcl-2, Bcl- $\mathrm{X}_{\mathrm{L}}$, and Bcl-w disrupts their anti-apoptotic functions and is associated with death of various tumour cells (Chauhan et al. 2007; Placzek et al. 2010). ABT-737-induced cell death exhibited all the 
characteristic ultrastructural changes of apoptosis induced by activation of caspase- 9 and was completely inhibited in cells deficient for Bax/Bak or caspase-9 (Vogler et al. 2009).

Since ABT-737 exhibits minimal affinity to another important anti-apoptotic member of Bcl-2 family Mcl-1 (Oltersdorf et al. 2005), sensitivity of tumour cells to ABT737 depends significantly on the relative expression levels of Bcl-2/ Bcl-X $\mathrm{L}_{\mathrm{L}}$ versus $\mathrm{Mcl}-1$ (Konopleva et al. 2006; van Delft et al. 2006) or Mcl-1 versus BIM and PUMA (PétignyLechartier et al. 2017). In agreement with this, down-regulation of Mcl-1 expression significantly enhances ABT-737 cytotoxicity (Chen et al. 2007; Lin et al. 2007; Lestini et al. 2009). On the other hand, ABT-737 displaces BIM from the $\mathrm{BH} 3$-binding pocket of $\mathrm{Bcl}-2$ that is associated with BIM-mediated activation of Bax and consequent initiation of mitochondrial apoptosis (Del Gaizo Moore et al. 2007). It seems that the extent of $\mathrm{Bcl}-2$ bound to BIM, rather than total Bcl-2 expression levels, may determine cellular sensitivity to ABT-737 (Deng et al. 2007). In hand with this, ABT-737 has been shown to interact with certain anticancer agents capable of up-regulating BIM (Kuroda et al. 2006; Zhang et al. 2008b; Stefaniková et al. 2013).

Inhibitors of cyclin-dependent kinase 2 (CDK2) including SU9516 exhibit also significant potential with respect to treatment of different types of malignant diseases (Asghar et al. 2015; Chohan et al. 2015) including CRC (Yamamoto et al. 1998). Down-regulation of Mcl-1 expression (Gao et al. 2006), down-regulation and phosphorylation of Mcl-1 associated with consequent release of BIM bound to Mcl-1 (Choudhary et al. 2015) as well as caspase-3 activation (Lane et al. 2001; Gao et al. 2006) were shown to be among the mechanisms involved in the cell death induction by CDK2 inhibitors.

The aim of presented study was to determine effect of ABT-737 as well as SU9516 alone and in combination with ABT-737 on survival of colorectal cell lines HT29 and Caco2. In addition, we have also focused our interest on the RT-PCR and Western blot analysis of the levels of selected proteins of Bcl-2 family in untreated HT29 and Caco- 2 cells as well as on the analysis of the impact of SU9516 on the levels of proteins of Bcl-2 family in the cells treated with SU9516 alone and in combination with ABT-737.

\section{Material and Methods}

SU9516 (Calbiochem), (3-(4,5-dimethylthiazol-2-yl)-2,5diphenyltetrazolium bromide (MTT), sodium dodecylsulphate (SDS) were from Sigma Aldrich, ABT-737 was from Abbott Laboratories. In this study were used rabbit polyclonal antibodies against Mcl-1 (SAB4501843) from Sigma-Aldrich, Bcl-X $\mathrm{L}_{\mathrm{L}}$ (sc-7195), BIM (sc-11425) and BAX (sc-439). Mouse monoclonal antibodies against p53
(SC-5576) and $\beta$-actin (SC-47778); mouse anti-rabbit (SC2357) and goat anti-mouse (SC-2005) were from Santa Cruz Biotechnology, secondary antibodies conjugated with horseradish peroxidase.

\section{Cell culture}

The HT29 and Caco-2 cell lines were purchased from ATCC. $\mathrm{HT} 29$ cells were grown at $37^{\circ} \mathrm{C} / 5 \% \mathrm{CO}_{2}$ in $\mathrm{McCoy}$ 's $5 \mathrm{a}$ medium (Sigma-Aldrich) supplemented with $10 \%$ foetal calf serum and $1 \%$ penicillin-streptomycin (all PAA). Caco-2 cells were grown at $37^{\circ} \mathrm{C} / 5 \% \mathrm{CO}_{2}$ in MEM-Earle (SigmaAldrich) containing nonessential amino acids and $2 \mathrm{mM}$ L-glutamine supplemented with $20 \%$ foetal calf serum and $1 \%$ penicillin-streptomycin (all PAA).

\section{Cell viability assay}

Both HT29 and Caco-2 cells were seeded in 96-well plates at concentrations of $4 \times 10^{5}$ per ml in $2 \times 10^{6}$ Caco- 2 cells per $\mathrm{ml}$ in triplicate wells and were incubated $24-72 \mathrm{~h}$ with or without various concentrations of ABT-737 and/or SU9516. At the end of incubation the absorbance of formazan that resulted from oxidation of added MTT by vital cells was determined spectrophotometrically using microplate reader BioRad 2010. The relative viability of the cells was determined as ratio of optical density of formazan produced by treated cells to optical density of formazan produced by non-treated control cells and expressed as per cent of control. The cell growth was determined as time course of optical density of formazan produced by particular cell population.

Isolation of total RNA and quantitative real time reversetranscription polymerase chain reaction ( $q R T-P C R)$ based on TaqMan ${ }^{\circledast}$ array

Total RNA was isolated from harvested cells using Tri reagent (Sigma-Aldrich) following the manufacturer's protocol. Total RNA $(5 \mu \mathrm{g})$ was reversely transcribed to cDNA using Maxima First Strand cDNA synthesis kit for RT-qPCR (Thermo Scientific) kit according to protocol supplied by manufacturer.

In our experiments, the predesigned 384-well microfluidic cards (TaqMan ${ }^{\circledR}$ array) with eight sample loading ports were used. The cards were configured into four identical 96gene sets containing assays for 93 human apoptosis-related genes in addition to three endogenous controls (18S RNA, actin and $G A P D H)$. The 93 genes were categorized into multiple target classes including genes coding for proteins involved in intrinsic, extrinsic, regulatory, and execution apoptosis traits. A reaction mixture prepared according to protocol supplied by manufacturer containing cDNA 
template $(100 \mathrm{ng})$ and a particular volume of TaqMan universal master mix (Applied Biosystems) was immediately loaded into each line of the TLDA microfluidic card. Each card was centrifuged twice at 1,200 rpm for $1 \mathrm{~min}$ to distribute the PCR mix into the wells of the card, before it was sealed and loaded into the ViiA ${ }^{\mathrm{mi}} 7$ Real-Time PCR System (Life Technologies). The thermal cycle conditions and the threshold cycle, $\mathrm{C}_{\mathrm{T}}$, were automatically assigned by the SDS2.2 software package (Life Technologies).

\section{Array normalization and selection of differentially expressed} genes

The arithmetic standard normalization procedures recommended by the Data Assist software for microarray data were followed. Data transformation was corrected for the signal from the endogenous control (ACTB). The relative changes in gene expression between cells were analysed using the $2^{-\Delta \Delta C_{T}}$ method (Schmittgen and Livak 2008) where $\Delta \Delta \mathrm{CT}=\left(\mathrm{C}_{\text {Ttarget }}-\mathrm{C}_{\mathrm{T}}\right)_{\mathrm{HT} 29 \text { cells }}-\left(\mathrm{C}_{\text {Ttarget }}-\mathrm{C}_{\mathrm{T}}\right)_{\text {Caco-2 cells }}$. Relative quantities (RQ) were determined using the equation $\mathrm{RQ}=2^{-\Delta \Delta C} \mathrm{~T}$. All data were generated in triplicate (different TLDA plates) and expressed as the mean fold change in expression of the particular gene in HT29 cells relative to the mean of the Caco- 2 cells. Differentially expressed genes were selected from the normalized data. Transcription of particular gene was considered to be significant when the average fold change was less than 0.5 for downregulated genes or more than 1.5 for upregulated genes, and statistically significant when the corresponding $p$ value was less than 0.05 .

\section{Western blotting}

Isolation of proteins was performed by extraction with TriReagent (Invitrogen) according to manufacturer's instructions. Extracted proteins were separated on $12 \%$ SDS-polyacrylamide gels under reducing conditions with $30 \mu \mathrm{g}$ of protein loaded per lane, transferred to nitrocellulose membrane via semidry transfer and probed with antibodies specific to p53, Mcl-1, Bcl-X $\mathrm{L}$, BIM, BAX and $\beta$-actin. After incubation of membranes with particular secondary antibodies, immunopositive bands were visualized using the chemiluminiscent substrate SuperSignal West Pico (Thermo Scientific) and Chemidoc XRS system (BioRad). Specific bands were documented by Quantity One software (BioRad).

\section{Statistical analysis}

All statistical analyses were done using GrafPhad InStat V2.04a (GrafPhad Software). The unpaired Tukey's test was used to determine differences between viability of control and treated cells. Significance level was set at $p<0.05$.

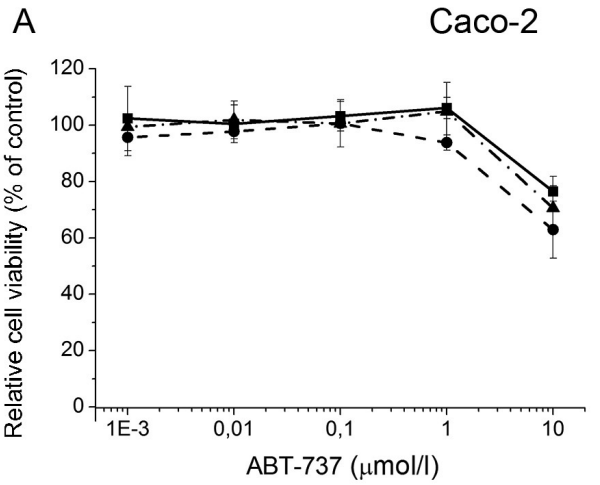

B

Caco-2

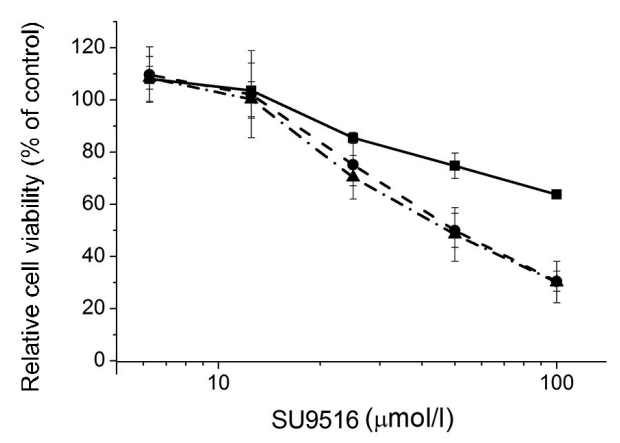

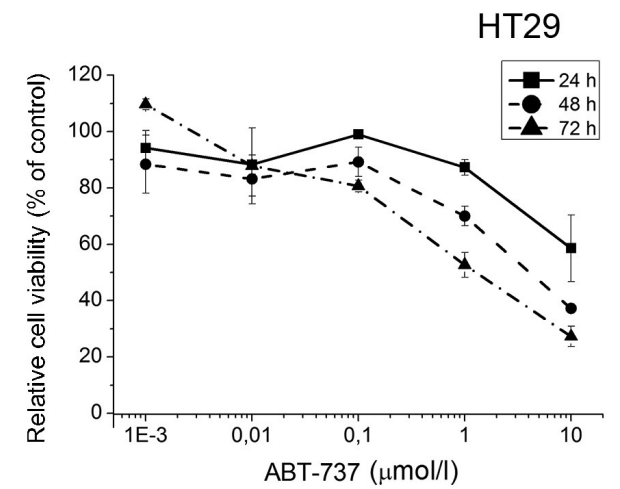

HT29

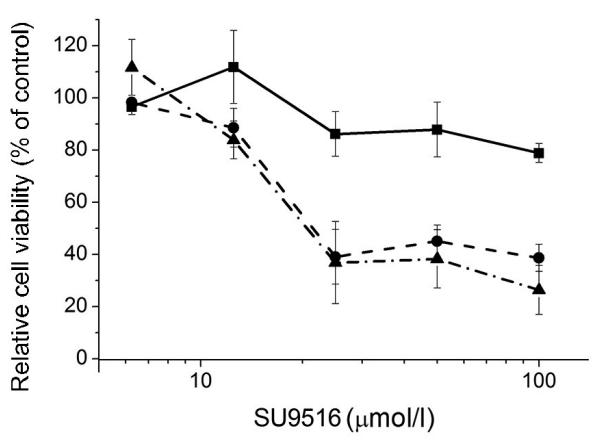

Figure 1. The effect of ABT-737 (A) and SU9516 (B) on relative viability of Caco-2 and HT29 cells. HT29 and Caco-2 cells were treated with indicated concentrations of ABT-737 and SU9516 for 24,48 , and $72 \mathrm{~h}$ and then the relative cell viability was determined by MTT test as described in Material and Methods. Data are presented as means \pm SEM (three independent experiments performed in triplicate per each cell line). 


\section{Results}

Treatment of the cells with ABT-737 for 24, 48 and $72 \mathrm{~h}$ has revealed time- and concentration-dependent impact of ABT-737 on relative viability of both Caco-2 and HT29 cells (Fig. 1A). The impact of ABT-737 on relative viability of Caco- 2 cells was faster and decrease of relative cell viability was already observed after $24 \mathrm{~h}$ of incubation. However, Caco- 2 cells were relative resistant and the relative viability of Caco- 2 cells at concentration of ABT-737 $10 \mu \mathrm{mol} / \mathrm{l}$ was $76.5 \pm 5.3 \%(p>0.05), 62.9 \pm 10.1 \%(p>0.05)$ and 70.6 $\pm 7.9 \%(p<0.05)$ after 24,48 and $72 \mathrm{~h}$, respectively. In contrary, significant decrease of relative viability of HT29 cells treated with ABT-737 was observed after 48 h but HT29 cells were significantly more sensitive to ABT-737. The $\mathrm{LC}_{50}$ values for ABT-737 were estimated to be $6.41 \pm 0.6$ and 2.5 $\pm 1.6 \mu \mathrm{mol} / \mathrm{l}$ after 48 and $72 \mathrm{~h}$, respectively.
The impact of SU9516 on relative viability of HT29 and Caco-2 cells was also time- and concentration-dependent (Fig. 1B). Caco-2 cells were also less sensitive to SU9516 and the $\mathrm{LC}_{50}$ values for SU9516 were estimated to be $49.9 \pm 6.4$, and $49.9 \pm 5.1 \mu \mathrm{mol} / \mathrm{l}$ after 48 and $72 \mathrm{~h}$, respectively. SU9516 in concentrations 25,50 and $100 \mu \mathrm{mol} / \mathrm{l}$ led to the significant decrease of relative viability of HT29 cells which was dominant after $48 \mathrm{~h}$ of incubation. The $\mathrm{LC}_{50}$ values for SU9516 were estimated to be $22.2 \pm 3.6$ and $21.5 \pm 4.1 \mu \mathrm{mol} / \mathrm{l}$ after 48 and $72 \mathrm{~h}$, respectively.

In order to test effect of SU9516 in combination with ABT-737 fixed concentrations of SU9516 (12.5 $\mu \mathrm{mol} / \mathrm{l})$ were used whereas concentrations of ABT-737 were varied in the complete investigated range. SU9516 in concentration $12.5 \mu \mathrm{mol} / 1 \mathrm{did}$ not exhibit significant impact on relative viability of Caco- 2 cells, while the same concentration decreased relative viability of HT29 cells to $88.6 \pm 7.4 \%$ ( $p>$

\section{A}

Caco-2
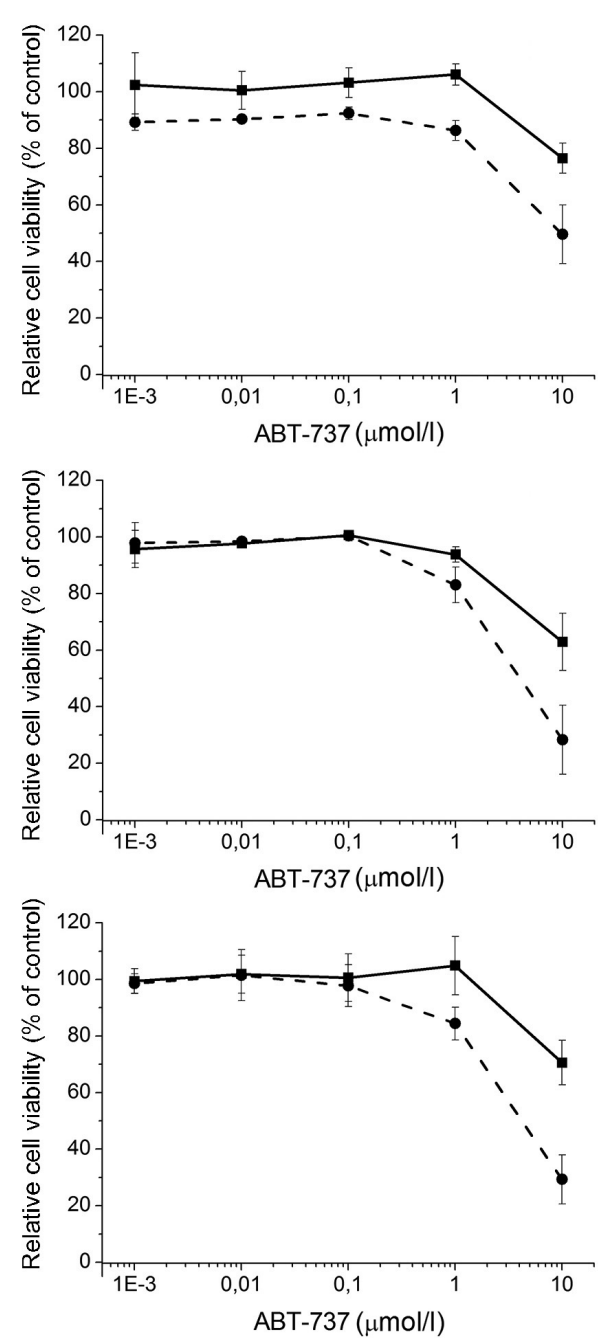

\section{B}
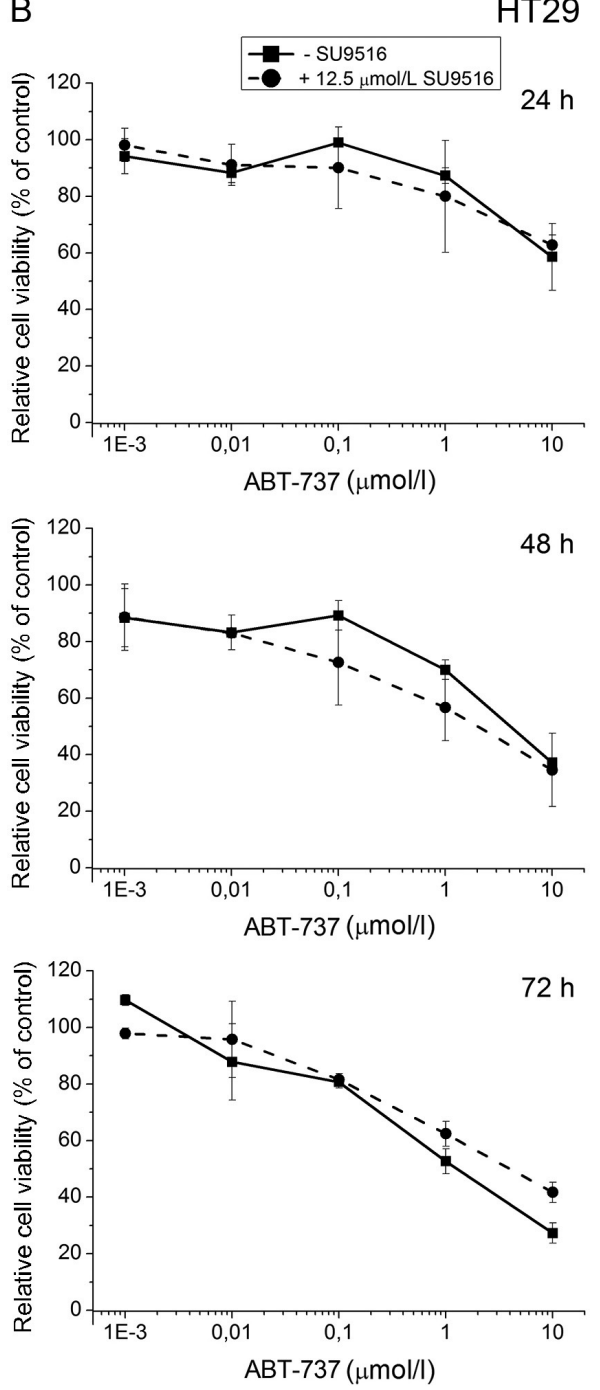

Figure 2. The effect of ABT-737 in combination with $12.5 \mu \mathrm{mol} / \mathrm{l}$ SU9516 on relative viability of Caco-2 (A) and HT29 (B) cells. Caco-2 and HT29 cells were treated with indicated concentrations of ABT-737 in combination with $12.5 \mu \mathrm{mol} / \mathrm{l}$ SU9516 for 24,48 , and $72 \mathrm{~h}$ and then the relative cell viability was determined by MTT test as described in Material and Methods. Data are presented as means \pm SEM (three independent experiments performed in triplicate per each cell line). 
A

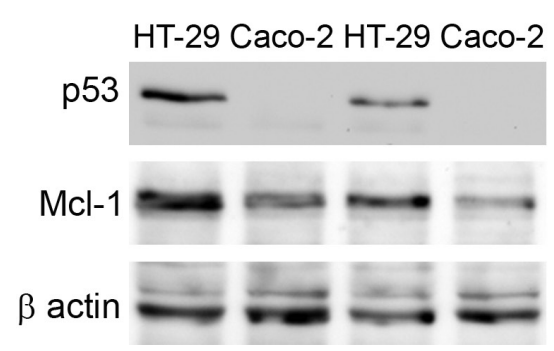

B

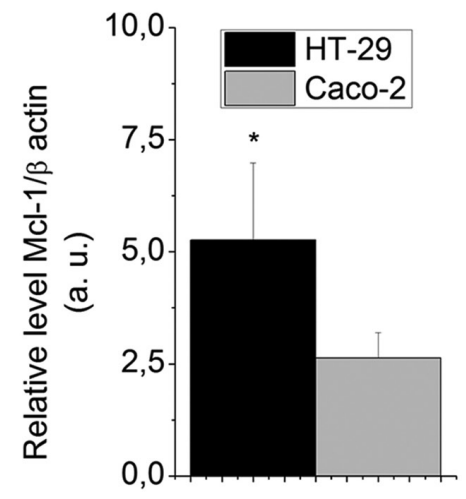

Figure 3. Levels of p53 and Mcl-1 in untreated HT29 and Caco- 2 cells. Total cell extracts were prepared from both untreated HT29 and Caco-2 cells. The levels of p53 and Mcl-1 were evaluated by Western blot analysis of total cell extracts as described in Materials and Methods. Data are presented as means $\pm \mathrm{SD}$ ( 4 independent experiments per each cell line). ${ }^{\star} p<0.05$, (Tukey's test to determine differences between levels of particular proteins in both types of cells).
$0.05)$ and $83.9 \pm 7.2 \%(p<0.05)$ after 48 and $72 \mathrm{~h}$, respectively. We have observed significant difference in the effect of ABT-737 on relative viability of Caco- 2 cells incubated in the absence or presence of $12.5 \mu \mathrm{mol} / 1$ SU9516 (Fig. 2A) for 24, 48 and $72 \mathrm{~h}$. The relative viability of Caco-2 cells incubated in the presence of $12.5 \mu \mathrm{mol} / \mathrm{l}$ of SU9516 was significantly decreased at concentrations of ABT-737 $10 \mu \mathrm{mol} / \mathrm{l}$ as compared to the relative viability of Caco- 2 cells incubated with ABT-737 only $(28.3 \pm 12.2 \%$ versus $62.9 \pm 10.1 \%$ after $48 \mathrm{~h}$ of incubation and $29.3 \pm 8.7 \%$ versus $70.6 \pm 7.9 \%$ after $72 \mathrm{~h}$ of incubation). In HT29 cells, addition of SU9516 did not affect the cytotoxic effect of ABT-737 (Fig. 2B).

In order to compare gene expression profile of genes coding for Bcl-2 family proteins, total RNA isolated from non-treated HT29 and Caco-2 cells was analysed by qRTPCR based on TaqMan ${ }^{\circledR}$ array human apoptosis panel. The results of $\mathrm{qRT}-\mathrm{PCR}$ analysis showing only significantly different expressed genes are presented in Table 1. In HT29 cells, significantly higher gene expression of pro-apoptotic/ anti-survival (BAX, BOK, BID, BIM, PUMA, Noxa) proteins of Bcl-2 family was observed. In the same cells, we have also documented significantly higher expression of gene coding for anti-survival protein Bcl-Rambo involved in induction of mitophagy (Murakawa et al. 2015). In Caco-2 cells, significantly higher gene expression of one pro-apoptotic/ anti-survival Bcl-2L14 (Bcl-g) protein of Bcl-2 family was observed.

In addition to the mRNA analysis, we have focused our interests on Western blot detection of selected proteins of Bcl-2 family, playing a role in sensitivity and resistance of malignant cells to ABT-737, in non-treated HT29 and Caco- 2 cells. Despite no changes observed by mRNA analysis, significantly higher level of Mcl-1 protein (196.9\% of Mcl-1 in Caco-2 cells, $p<0.05)$ was detected in HT29 cells (Fig. 3). The levels of other investigated Bcl-2 family proteins $\left(\mathrm{Bcl}-\mathrm{X}_{\mathrm{L}}, \mathrm{BIM}\right.$ and BAX) were not significantly different (results not shown). In addition to proteins of Bcl-2 family we have analysed expression of tumour suppressor protein p53 that was detected in HT29 cells but not in Caco-2 cells.

We have also investigated the effect of SU9516 alone and in combination with ABT-737 on expression of Mcl-1 and p53. As shown on Fig. 4, incubation of Caco-2 cells with either SU9516 or SU9516 in combination with ABT-737 was associated with decrease in Mcl-1 protein level observed after 48 and $72 \mathrm{~h}$ incubation. The level of Mcl-1 protein was unaltered in HT29 cells treated with SU9516 alone or in combination with ABT-737. However, we have observed

Table 1. Gene expression profiling of anti-survival proteins of Bcl-2 family in HT29 and Caco-2 cells

\begin{tabular}{lllcl}
\hline Gene name & ENSEMBL gene number & Fold change & $p$ & Gene description \\
\hline BAX & ENSG00000087088 & 3.4 & 0.0007 & BCL2-associated X protein, BAX \\
BOK & ENSG00000176720 & 14.4 & 0.0018 & BCL2-related ovarian killer \\
BID & ENSG00000015475 & 3.5 & 0.0068 & BH3 interacting domain death agonist \\
BBC3 & ENSG00000105327 & 33.8 & 0.0002 & BCL2 binding component 3, PUMA \\
PMAIP1 & ENSG00000141682 & 21.1 & 0.0006 & phorbol-12-myristate-13-acetate-induced protein 1, Noxa \\
BCL2L11 & ENSG00000153094 & 2 & 0.0098 & BCL2-like 11, BIM \\
BCL2L13 & ENSG00000099968 & 3.3 & 0.0022 & BCL2-like 13, Bcl-Rambo \\
BCL2L14 & ENSG00000121380 & 0.53 & 0.0002 & BCL2-like 14, Bcl-g \\
\hline
\end{tabular}




\begin{tabular}{|c|c|c|c|c|c|c|c|c|c|c|}
\hline & & & 241 & & & 48 & & & $72 \mathrm{I}$ & \\
\hline & ABT-737 & - & - & + & - & - & + & - & - & + \\
\hline co-2 & SU9516 & - & + & + & $\begin{array}{lll}- & -\end{array}$ & + & + & - & + & + \\
\hline & Mcl-1 & - & - & - & - & - & - & - & - & - \\
\hline & ac & & & & & & - & & & - \\
\hline
\end{tabular}

HT-29

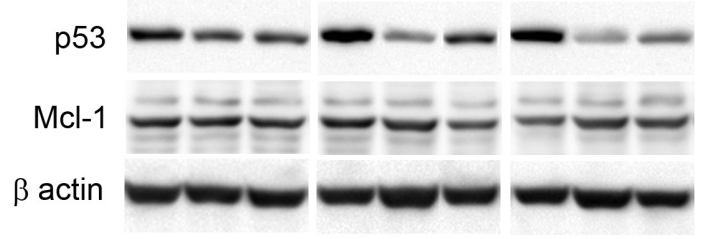

Figure 4. The effect of SU9516 alone and in combination with ABT-737 on the level of Mcl-1. Total cell extracts were prepared from both HT29 and Caco-2 cells after the treatment with either $12.5 \mu \mathrm{mol} / \mathrm{l}$ or $12.5 \mu \mathrm{mol} / \mathrm{l}$ of SU9516 in combination with $10 \mu \mathrm{mol} / \mathrm{l}$ ABT-737 for 24, 48 and $72 \mathrm{~h}$. The effect of treatments on the levels of p53 and Mcl-1 was evaluated by Western blot analysis of total cell extracts as described in Material and Methods.

decreased expression of p53 protein in HT29 cells treated with SU9516 alone or in combination with ABT-737 after 48 and 72 h (Fig. 4).

\section{Discussion}

In this study, we have shown that both Caco-2 and HT29 cells are relatively resistant to ABT-737 as well as that CDK2 inhibitor SU9516 despite inducing cell death of both CRC cell lines used in the study increases sensitivity of Caco-2 but not HT29 cells to ABT-737.

The relative resistance of both Caco- 2 and HT29 cells to ABT-737 correlated well with the fact that both HT29 and Caco-2 cells are negative for expression of Bcl-2 (on both mRNA and protein level, data not shown) since Bcl-2 was shown to be a better ABT-737 target than Bcl- $\mathrm{X}_{\mathrm{L}}$ or $\mathrm{Bcl}-\mathrm{W}$ (Rooswinkel et al. 2012). In agreement, the CRC cells HCT116, expressing significant amounts of $\mathrm{Bcl}-2$ protein and the same level of $\mathrm{Bcl}-\mathrm{X}_{\mathrm{L}}$ protein as HT29 cells, were much more sensitive to ABT-737 than Bcl-2 negative HT29 cells (Okumura et al. 2008). We have also shown the higher sensitivity of HT29 cells than Caco-2 cells to ABT-737 that was in agreement with previously published data (Koehler et al. 2014).

In addition to ABT-737, we have also documented different sensitivity of Caco-2 and HT29 cells to CDK2 inhibitor SU9516. Caspase-3-dependent mitochondrial apoptosis has been documented as the major mechanism of SU9516induced death of tumour cells (Gao et al. 2006) including HT29 cells (Lane et al. 2001). In agreement, we have documented down-regulation of Mcl-1 protein in Caco-2 since down-regulation of Mcl-1 expression or inhibition of Mcl-1 function have been shown to be associated with caspase-3-dependent apoptosis initiation and consequent death of different types of cancer cells (for review see Belmar and Fesik 2015). In HT29 cells, we have not observed down-regulation of Mcl-1 after the treatment with SU9516. Instead of this, we have shown that treatment of HT29 cells with SU9516 was associated with decreased expression of tumour suppressor protein p53. In normal cells, wild type tumour suppressor protein p53 is quickly eliminated and its expression is stabilised after damage to DNA or other intracellular stress conditions (Bullock and Fersht 2001) while in tumour cells p53 is frequently mutated and the mutation have different impact on p53 function and stability (Muller and Vousden 2013). Tumour cell bearing some nonsense mutations of p53 including Caco-2 cells (Liu and Bodmer 2006) do not express p53 protein while the cells expressing some missense mutations of p53 that are highly frequent in CRC (Soussi and Wiman 2015) are characterised by overexpression of mutated p53 (for review see Brosh and Rotter 2009). We have shown stable expression of $\mathrm{p} 53$ protein in HT29 cells that are expressing p53 bearing R273H missense mutation (Leroy et al. 2014). Such mutation is associated with gain of function of p53 protein leading to increased resistance of the tumour cells to chemotherapy (Wong et al. 2007), increased invasion and metastatic progression of the tumour cells (Oren and Rotter 2010) including HT29 (Muller et al. 2013). In addition, it has been shown that knockdown of $\mathrm{R} 273 \mathrm{H}$ mutant $\mathrm{p} 53$ is associated with increased sensitivity of tumour cells to chemotherapy via increase of procaspase-3 expression and activation (Wong et al. 2007).

As mentioned above, sensitivity of the tumour cells to ABT737 can be increased by down-regulation of Mcl-1 (Chen et al. 2007; Lin et al. 2007) and consequent release of Mcl-1 from the binding to BIM protein (Mazumder et al. 2012; Choudhary et al. 2015) that can be achieved by the treatment of some cells with inhibitors of CDK2 including SU9516 (Gao et al. 2006). Despite low sensitivity of Caco-2 cells to SU9516, combination of SU9516 with ABT-737 was associated with increased sensitivity of Caco- 2 cells to ABT-737 while sensitivity of HT29 cells to ABT-737 was unaltered after the treatment of HT29 cells with ABT-737 in combination with SU9516. Our results are consistent with a view that increased sensitivity of Caco- 2 cells to ABT-737 after addition of SU9516 is related to SU9516-induced decrease of Mcl-1 expression since our Western blot experiments revealed decrease of Mcl-1 expression $48 \mathrm{~h}$ after the treatment of Caco-2 cells with SU9516 and combination of ABT-737 with SU9516. The time course of decreased Mcl-1 expression correlated well with the MTT experiments that also showed positive effect of SU9516 on sensitivity to ABT-737 after the treatment of the cells with ABT-737 in combination with SU9516 for $48 \mathrm{~h}$ and more. 
Our results are also in agreement with study documented that CDK2 inhibition by dinaciclib resulted in downregulation of Mcl-1 and the combination of dinaciclib with ABT-737 resulted in robust synergistic cell death in leukemic cells and primary chronic lymphocytic leukaemia patient samples (Choudhary et al. 2015). Treatment of HT29 with SU9516 was not associated with decrease of Mcl-1 expression that provides rational explanation about inefficiency of SU9516 to increase sensitivity of HT29 cells to ABT-737. Regulation of expression of Mcl-1 in cancer cells is very complex and depends on transcriptional, post-transcriptional and posttranslational control (see for review Juin et al. 2014). It has been documented that CDK2-dependent phosphorylation of Mcl-1 resulted in increased Mcl-1 stability (Thr92, and Thr163) and BIM binding (Ser64) and CDK2 inhibition resulted in downregulation of $\mathrm{Mcl}-1$ and BIM release from Mcl-1 in ABT-737 resistant cells (Choudhary et al. 2015). Mcl-1 can also be downregulated after the treatment with ABT-737 via caspase-3-mediated cleavage (Ryu et al. 2014). Additional effect of SU9516 to ABT-737 can be explained by the fact that inhibition of Mcl-1 phosphorylation is also associated with release of Mcl-1 from the binding to BIM that is pro-apoptotic $\mathrm{BH} 3$-only protein with great potential to induce ABT-737-mediated mitochondrial apoptosis (Del Gaizo Moore et al. 2007; Zhang et al. 2008b). Thus, our results related to Caco- 2 cells are consistent with a view that phosphorylation of Mcl-1 is the major determinant of ABT-737 resistance in MCl-1 expressing cells (Mazumder et al. 2012). We can only speculate about the fact that Mcl-1 was not downregulated in HT29 cells after the treatment with SU9516. Interestingly, multikinase inhibitor BAY 43-9006 that downregulates Mcl-1 through inhibition of translation (Rahmani et al. 2005) or proteasomal degradation (Yu et al. 2005) was shown to downregulate Mcl-1 also in HT29 cells (Yu et al. 2005). Unlike ABT-737, pan-Bcl-2 inhibitor Obatoclax that binds to Bcl-2, Bcl-X $\mathrm{L}_{\mathrm{L}}, \mathrm{Bcl}-\mathrm{w}$ and Mcl-1 (Konopleva et al. 2008) was shown to be a potent late stage autophagy inhibitor in HT29 cells, causing cell growth arrest and cell death (Koehler et al. 2015).

In conclusion, our findings provide a rationale for clinical use of Bcl-2 family inhibitors in combination with CDK2 inhibitors for treatment of Mcl-1-dependent colorectal tumours associated with expression of $\mathrm{Bcl}-2, \mathrm{Bcl}-\mathrm{X}_{\mathrm{L}}$ and $\mathrm{Bcl}-\mathrm{w}$ proteins. In addition, we have documented potential of CDK2 inhibitors for treatment of tumours expressing R273H mutant p53.

Acknowledgments. This work was supported by the Slovak Research and Development Agency under the contract No. APVV0224-12 (to JH), by the project Biomedical Center Martin (ITMS: 26220220187) co-financed from EU sources and by the project Creating a New Diagnostic Algorithm for Selected Cancer Diseases (to PR) (ITMS: 26220220022) co-financed from EU sources and the European Regional Development Fund.

\section{References}

Asghar U., Witkiewicz A. K., Turner N. C., Knudsen E. S. (2015): The history and future of targeting cyclin-dependent kinases in cancer therapy. Nat. Rev. Drug Discov. 14, 130-146 https://doi.org/10.1038/nrd4504

Ashkenazi A., Fairbrother W. J., Leverson J. D., Souers A. J. (2017): From basic apoptosis discoveries to advanced selective BCL-2 family inhibitors. Nat. Rev. Drug Discov. 16, 273-284 https://doi.org/10.1038/nrd.2016.253

Belmar J., Fesik S. W. (2015): Small molecule Mcl-1 inhibitors for the treatment of cancer. Pharmacol. Ther. 145, 76-84 https://doi.org/10.1016/j.pharmthera.2014.08.003

Brosh R., Rotter V. (2009): When mutants gain new powers: news from the mutant p53 field. Nat. Rev. Cancer 9, 701-713 https://doi.org/10.1038/nrc2693

Bullock A. N., Fersht A. R. (2001): Rescuing the function of mutant p53. Nat. Rev. Cancer. 1, 68-76 https://doi.org/10.1038/35094077

Chauhan D., Velankar M., Brahmandam M., Hideshima T., Podar K., Richardson P., Schlossman R., Ghobrial I., Raje N., Munshi N., Anderson K. C. (2007): A novel Bcl-2/Bcl-X(L)/Bcl-w inhibitor ABT-737 as therapy in multiple myeloma. Oncogene 26, 2374-2380 https://doi.org/10.1038/sj.onc.1210028

Chen S., Dai Y., Harada H., Dent P., Grant S. (2007): Mcl-1 downregulation potentiates ABT-737 lethality by cooperatively inducing Bak activation and Bax translocation. Cancer Res. 67, 782-791 https://doi.org/10.1158/0008-5472.CAN-06-3964

Chohan T. A, Qian H., Pan Y., Chen J. Z. (2015): Cyclin-dependent kinase-2 as a target for cancer therapy: progress in the development of CDK2 inhibitors as anti-cancer agents. Curr. Med. Chem. 22, 237-263 https://doi.org/10.2174/0929867321666141106113633

Choudhary G. S., Tat T. T., Misra S., Hill B. T., Smith M. R., Almasan A., Mazumder S. (2015): Cyclin E/Cdk2-dependent phosphorylation of Mcl-1 determines its stability and cellular sensitivity to BH3 mimetics. Oncotarget 6, 16912-16925 https://doi.org/10.18632/oncotarget.4857

Czabotar P. E., Lessene G., Strasser A., Adams J. M. (2014): Control of apoptosis by the BCL-2 protein family: implications for physiology and therapy. Nat. Rev. Mol. Cell Biol. 15, 49-63 https://doi.org/10.1038/nrm3722

Delbridge A. R., Grabow S., Strasser A., Vaux D. L. (2016): Thirty years of BCL-2: translating cell death discoveries into novel cancer therapies. Nat. Rev. Cancer 16, 99-109 https://doi.org/10.1038/nrc.2015.17

Del Gaizo Moore V., Brown J. R., Certo M., Love T. M., Novina C. D., Letai A. (2007): Chronic lymphocytic leukemia requires BCL2 to sequester prodeath BIM, explaining sensitivity to BCL2 antagonist ABT-737. J. Clin. Investig. 117, 112-121 https://doi.org/10.1172/JCI28281

Deng J., Carlson N., Takeyama K., Dal Cin P., Shipp M., Letai A. (2007): BH3 profiling identifies three distinct classes of apoptotic blocks to predict response to ABT-737 and conventional chemotherapeutic agents. Cancer Cell 12, 171-185 https://doi.org/10.1016/j.ccr.2007.07.001 
Dienstmann R., Vermeulen L., Guinney J., Kopetz S., Tejpar S., Tabernero J. (2017): Consensus molecular subtypes and the evolution of precision medicine in colorectal cancer. Nat. Rev. Cancer 17, 79-92 https://doi.org/10.1038/nrc.2016.126

Ferlay J., Shin H. R., Bray F., Forman D., Mathers C., Parkin D. M. (2010): Estimates of worldwide burden of cancer in 2008: GLOBOCAN 2008. Int. J. Cancer 127, 2893-2917 https://doi.org/10.1002/ijc.25516

Gao N., Kramer L., Rahmani M., Dent P., Grant S. (2006): The threesubstituted indolinone cyclin-dependent kinase 2 inhibitor 3-[1-(3H-imidazol-4-yl)-meth-(Z)-ylidene]-5-methoxy-1,3dihydro-indol-2-one (SU9516) kills human leukemia cells via down-regulation of Mcl-1 through a transcriptional mechanism. Mol. Pharmacol. 70, 645-655 https://doi.org/10.1124/mol.106.024505

Hatok J., Racay P. (2016): Bcl-2 family proteins: master regulators of cell survival. Biomol. Concepts 7, 259-270 https://doi.org/10.1515/bmc-2016-0015

Jin-Song Y., Zhao-Xia W., Cheng-Yu L., Xiao-Di L., Ming S., YuanYuan G., Wei D. (2011): Prognostic significance of Bcl-xL gene expression in human colorectal cancer. Acta Histochem. 113, 810-814 https://doi.org/10.1016/j.acthis.2011.01.002

Juin P., Geneste O., Gautier F., Depil S., Campone M. (2013): Decoding and unlocking the BCL-2 dependency of cancer cells. Nat. Rev. Cancer 13, 455-465 https://doi.org/10.1038/nrc3538

Koehler B. C., Scherr A. L., Lorenz S., Elssner C., Kautz N., Welte S., Jaeger D., Urbanik T., Schulze-Bergkamen H. (2014): Pan-Bcl-2 inhibitor obatoclax delays cell cycle progression and blocks migration of colorectal cancer cells. PLoS One 9, e106571 https://doi.org/10.1371/journal.pone.0106571

Koehler B. C., Jassowicz A., Scherr A. L., Lorenz S., Radhakrishnan P., Kautz N., Elssner C., Weiss J., Jaeger D., Schneider M., Schulze-Bergkamen H. (2015): Pan-Bcl-2 inhibitor Obatoclax is a potent late stage autophagy inhibitor in colorectal cancer cells independent of canonical autophagy signaling. BMC Cancer 15, 919 https://doi.org/10.1186/s12885-015-1929-y

Konopleva M., Contractor R., Tsao T., Samudio I., Ruvolo P. P., Kitada S., Deng X., Zhai D., Shi X. Y., Sneed T. et al. (2006): Mechanisms of apoptosis sensitivity and resistance to the $\mathrm{BH} 3$ mimetic ABT-737 in acute myeloid leukemia. Cancer Cell 10, 375-388 https://doi.org/10.1016/j.ccr.2006.10.006

Konopleva M., Watt J., Contractor R., Tsao T., Harris D., Estrov Z., Bornmann W., Kantarjian H., Viallet J., Samudio I., Andreeff M. (2008): Mechanisms of antileukemic activity of the novel Bcl-2 homology domain-3 mimetic GX15-070 (obatoclax). Cancer Res. 68, 3413-3420 https://doi.org/10.1158/0008-5472.CAN-07-1919

Krajewska M., Moss S. F., Krajewski S., Song K., Holt P. R., Reed J. C. (1996): Elevated expression of Bcl-X and reduced Bak in primary colorectal adenocarcinomas. Cancer Res. 56, 2422-2427

Kuroda J., Puthalakath H., Cragg M. S., Kelly P. N., Bouillet P., Huang D. C., Kimura S., Ottmann O. G., Druker B. J., Villunger A. et al. (2006): Bim and Bad mediate imatinib-induced killing of $\mathrm{Bcr} / \mathrm{Abl}$ leukemic cells, and resistance due to their loss is overcome by a BH3 mimetic. Proc. Natl. Acad. Sci. USA 103, 14907-14912

https://doi.org/10.1073/pnas.0606176103

Lane M. E., Yu B., Rice A., Lipson K. E., Liang C., Sun L., Tang C., McMahon G., Pestell R. G., Wadler S. (2001): A novel cdk2-selective inhibitor, SU9516, induces apoptosis in colon carcinoma cells. Cancer Res. 61, 6170-6177

Lansdorp-Vogelaar I., van Ballegooijen M., Zauber A. G., Habbema J. D., Kuipers E. J. (2009): Effect of rising chemotherapy costs on the cost savings of colorectal cancer screening. J. Natl. Cancer Inst. 101, 1412-1422

https://doi.org/10.1093/jnci/djp319

Leroy B., Girard L., Hollestelle A., Minna J. D., Gazdar A. F., Soussi T. (2014): Analysis of TP53 mutation status in human cancer cell lines: a reassessment. Hum. Mutat. 35, 756-765 https://doi.org/10.1002/humu.22556

Lestini B. J., Goldsmith K. C., Fluchel M. N., Liu X., Chen N. L., Goyal B., Pawel B. R., Hogarty M. D. (2009): Mcl1 downregulation sensitizes neuroblastoma to cytotoxic chemotherapy and small molecule Bcl2-family antagonists. Cancer Biol. Ther. 8, 1587-1595 https://doi.org/10.4161/cbt.8.16.8964

Lin X., Morgan-Lappe S., Huang X., Li L., Zakula D. M., Vernetti L. A., Fesik S. W., Shen Y. (2007): ,Seed' analysis of off-target siRNAs reveals an essential role of Mcl-1 in resistance to the small-molecule Bcl-2/Bcl-xl inhibitor ABT-737. Oncogene 26, 3972-3979 https://doi.org/10.1038/sj.onc. 1210166

Liu Y., Bodmer W. F. (2006): Analysis of P53 mutations and their expression in 56 colorectal cancer cell lines. Proc. Natl. Acad. Sci. USA 103, 976-981 https://doi.org/10.1073/pnas.0510146103

Mazumder S., Choudhary G. S., Al-Harbi S., Almasan A. (2012): Mcl-1 Phosphorylation defines ABT-737 resistance that can be overcome by increased NOXA expression in leukemic B cells. Cancer Res. 72, 3069-3079 https://doi.org/10.1158/0008-5472.CAN-11-4106

Muller P. A., Trinidad A. G., Timpson P., Morton J. P., Zanivan S., van den Berghe P. V., Nixon C., Karim S. A., Caswell P. T., Noll J. E. et al. (2013): Mutant p53 enhances MET trafficking and signalling to drive cell scattering and invasion. Oncogene 32, 1252-1265 https://doi.org/10.1038/onc.2012.148

Muller P. A., Vousden K. H. (2013): p53 mutations in cancer. Nat. Cell Biol. 15, 2-8 https://doi.org/10.1038/ncb2641

Murakawa T., Yamaguchi O., Hashimoto A., Hikoso S., Takeda T., Oka T., Yasui H., Ueda H., Akazawa Y., Nakayama H. et al. (2015): Bcl-2-like protein 13 is a mammalian Atg32 homologue that mediates mitophagy and mitochondrial fragmentation. Nat. Commun. 6, 7527

https://doi.org/10.1038/ncomms8527

Okumura K., Huang S., Sinicrope F. A. (2008): Induction of Noxa sensitizes human colorectal cancer cells expressing Mcl-1 to the small-molecule Bcl-2/Bcl-xL inhibitor, ABT-737. Clin. Cancer Res. 14, 8132-8142 https://doi.org/10.1158/1078-0432.CCR-08-1665 
Oltersdorf T., Elmore S. W., Shoemaker A. R., Armstrong R. C., Augeri D. J., Belli B. A., Bruncko M., Deckwerth T. L., Dinges J., Hajduk P. J. et al. (2005): An inhibitor of Bcl-2 family proteins induces regression of solid tumours. Nature 435, 677-681 https://doi.org/10.1038/nature03579

Oren M., Rotter V. (2010): Mutant p53 gain-of-function in cancer. Cold Spring Harb. Perspect. Biol. 2, a001107 https://doi.org/10.1101/cshperspect.a001107

Pétigny-Lechartier C., Duboc C., Jebahi A., Louis M. H., Abeilard E., Denoyelle C., Gauduchon P., Poulain L., Villedieu M. (2017): The mTORC1/2 inhibitor AZD8055 strengthens the efficiency of the MEK inhibitor trametinib to reduce the Mcl-1/[Bim and Puma] ratio and to sensitize ovarian carcinoma cells to ABT737. Mol. Cancer Ther. 16, 102-115 https://doi.org/10.1158/1535-7163.MCT-16-0342

Placzek W. J., Wei J., Kitada S., Zhai D., Reed J. C., Pellecchia M. (2010): A survey of the anti-apoptotic Bcl-2 subfamily expression in cancer types provides a platform to predict the efficacy of Bcl-2 antagonists in cancer therapy. Cell Death Dis. 1, e40 https://doi.org/10.1038/cddis.2010.18

Rahmani M., Davis E. M., Bauer C., Dent P., Grant S. (2005): Apoptosis induced by the kinase inhibitor BAY 43-9006 in human leukemia cells involves down-regulation of Mcl-1 through inhibition of translation. J. Biol. Chem. 280, 35217-35227 https://doi.org/10.1074/jbc.M506551200

Rooswinkel R. W., van de Kooij B., Verheij M., Borst J. (2012): Bcl-2 is a better ABT-737 target than Bcl-xL or Bcl-w and only Noxa overcomes resistance mediated by Mcl-1, Bfl-1, or Bcl-B. Cell Death Dis. 3, e366 https://doi.org/10.1038/cddis.2012.109

Ryu Y., Hall C. P., Reynolds C. P., Kang M. H. (2014): Caspasedependent Mcl-1 cleavage and effect of Mcl-1 phosphorylation in ABT-737-induced apoptosis in human acute lymphoblastic leukemia cell lines. Exp. Biol. Med. (Maywood) 239, 1390-1402 https://doi.org/10.1177/1535370214538745

Schenk R. L., Strasser A., Dewson G. (2017): BCL-2: Long and winding path from discovery to therapeutic target. Biochem. Biophys. Res. Commun. 482, 459-469 https://doi.org/10.1016/j.bbrc.2016.10.100

Scherr A. L., Gdynia G., Salou M., Radhakrishnan P., Duglova K., Heller A., Keim S., Kautz N., Jassowicz A., Elssner C. et al. (2016): Bcl-xL is an oncogenic driver in colorectal cancer. Cell Death Dis. 7, e2342. 3 https://doi.org/10.1038/cddis.2016.233

Schmittgen T. D., Livak K. J. (2008): Analyzing real-time PCR data by the comparative $\mathrm{C}(\mathrm{T})$ method. Nat. Protoc. 3, 1101-1108 https://doi.org/10.1038/nprot.2008.73

Soussi T., Wiman K. G. (2015): TP53: an oncogene in disguise. Cell Death Differ. 22, 1239-1249 https://doi.org/10.1038/cdd.2015.53

Stefaniková A., Kliková K., Hatok J., Račay P. (2013): ABT-737 accelerates butyrate-induced death of HL-60 cells. Involvement of mitochondrial apoptosis pathway. Gen. Physiol. Biophys. 32, 505-516 https://doi.org/10.4149/gpb_2013053

van Delft M. F., Wei A. H., Mason K. D., Vandenberg C. J., Chen L., Czabotar P. E., Willis S. N., Scott C. L., Day C. L., Cory S. et al. (2006): The BH3 mimetic ABT-737 targets selective Bcl-2 proteins and efficiently induces apoptosis via Bak/Bax if Mcl-1 is neutralized. Cancer Cell 10, 389-399 https://doi.org/10.1016/j.ccr.2006.08.027

Vogler M., Weber K., Dinsdale D., Schmitz I., Schulze-Osthoff K., Dyer M. J., Cohen G. M. (2009): Different forms of cell death induced by putative BCL2 inhibitors. Cell Death Differ. 16, 1030-1039 https://doi.org/10.1038/cdd.2009.48

Wilson J. W., Nostro M. C., Balzi M., Faraoni P., Cianchi F., Becciolini A., Potten C. S. (2000): Bcl-w expression in colorectal adenocarcinoma. Br. J. Cancer 82, 178-185 https://doi.org/10.1054/bjoc.1999.0897

Wong R. P., Tsang W. P., Chau P. Y., Co N. N., Tsang T. Y., Kwok T. T. (2007): p53-R273H gains new function in induction of drug resistance through down-regulation of procaspase-3. Mol. Cancer Ther. 6, 1054-1061

https://doi.org/10.1158/1535-7163.MCT-06-0336

Yamamoto H., Monden T., Miyoshi H., Izawa H., Ikeda K., Tsujie M., Ohnishi T., Sekimoto M., Tomita N., Monden M. (1998): $\mathrm{Cdk} 2 / \mathrm{cdc} 2$ expression in colon carcinogenesis and effects of $\mathrm{cdk} 2 / \mathrm{cdc} 2$ inhibitor in colon cancer cells. Int. J. Oncol. 13, 233-239

https://doi.org/10.3892/ijo.13.2.233

Yu C., Bruzek L. M., Meng X. W., Gores G. J., Carter C. A., Kaufmann S. H., Adjei A. A. (2005): The role of Mcl-1 downregulation in the proapoptotic activity of the multikinase inhibitor BAY 43-9006. Oncogene 24, 6861-6869 https://doi.org/10.1038/sj.onc.1208841

Zhang Y. L., Pang L. Q., Wu Y., Wang X. Y., Wang C. Q., Fan Y. (2008a): Significance of Bcl-xL in human colon carcinoma. World J. Gastroenterol. 14, 3069-3073

https://doi.org/10.3748/wjg.14.3069

Zhang W., Konopleva M., Ruvolo V. R., McQueen T., Evans R. L., Bornmann W. G., McCubrey J., Cortes J., Andreeff M. (2008b): Sorafenib induces apoptosis of AML cells via Bim-mediated activation of the intrinsic apoptotic pathway. Leukemia 22, $808-818$

https://doi.org/10.1038/sj.leu.2405098

Received: March 31, 2017

Final version accepted: July 16, 2017 